\title{
MENAKAR KEBERAGAMAAN MASYARAKAT DAN \\ SOLIDARITAS MEMBANGUN MASJID (STUDI \\ KASUS MASJID DARUL HIDAYAH KELURAHAN \\ DASAN CERMEN KECAMATAN SANDUBAYA \\ KOTA MATARAM)
}

\author{
Nazar Naamy \\ Email: nazarpascamataram@gmail.com
}

\begin{abstract}
Religiousness is the knowledge level, belief, realization and full of comprehension of a person for the religion teachings which he believes, or an attitude of surrender to an existing strength outside of himself embodied in the activities and individual behavior in everyday life which include five dimensions: religious beliefs, worship, religion practice, religious knowledge, full of comprehension, and religious practice. The main problems in this research are: How is the understanding of Islam in the community of DasanCermen Village, Sandubaya Sub-district, Mataram City? How is practice of the teachings of Islam in the community of DasanCermen Village, Sandubaya Sub-District, Mataram City? What do factors influence people's spirit in building DarulHidayah mosque in DasanCermen village, Sandubaya Sub-district, Mataram City?
\end{abstract}

The purpose of this research is to analyze the religiousness level of Dasan Cermen community and solidarity to build a mosque by using the sociology theory of Emile Durkheim. The type of this research was field study (field research) and the method used was qualitative data analysis that is analytic descriptive. This research also used phenomenology approach which included: daily activities of society, talks directly or indirectly, forms of religious activity, and intensity of society in the utilization of mosques. F r o m the study conducted, this research found that the factors which encourage the DasanCermen community to build a mosque is a factor of ideology of rewardfrom Allah, a good collective solidarity passed down through the rural society, written rules and on the demands of sodakoh of road users who are so enthusiastic for the establishment of Darul Hidayah mosque. In addition, the 
DasanCermen community already has a mechanical solidarity to ideology in building a mosque. Although DasanCermen community is urban society, solidarity in building mosque is seen from the ideology of their religious understanding. This ideology also evolved as their mechanical solidarity as a rule which has been passed down from its predecessors, because the people still have a solid communal life in which the citizens have same interests and same awareness.

Keywords: Religiousness, Solidarity, Building a Mosque, Dasan Cermen Society

\section{A. Pendahuluan}

Keberagamaan (Religiosity) yang dikemukakan oleh C.Y Glock dan R. Stark Roland Robertson adalah tingkat pengetahuan, keyakinan, pelaksanaan dan penghayatan seseorang atas ajaran agama yang diyakininya, atau suatu sikap penyerahan diri kepada suatu kekuatan yang ada diluar dirinya yang diwujudkan dalam aktivitas dan perilaku individu sehari-sehari meliputi lima aspek-aspek atau dimensi yaitu keyakinan agama (ideologis), peribadatan atau praktik agama (ritualistik), pengetahuan agama (education), penghayatan(eksperiensial), pengamalan agama (Konsekuensial). Keyakinan agama adalah kepercayaan atas doktrin teologis, seperti percaya terhadap adanya Tuhan, Malaikat, Hari akhir, Surga, Neraka, Takdir, dan lainlain. Ibadah adalah cara melakukan penyembahan kepada Tuhan dengan segala rangkaiannya. Pengetahuan agama adalah pengetahuan tentang ajaran agama meliputi berbagai dimensi. Pengalaman agama adalah perasaan yang dialami oleh orang beragama, seperti rasa tenang, tenteram, bahagia, syukur, patuh, taat, takut, menyesal, bertobat, dll. Terakhir, pengamalan agama merupakan konsekuensi dari keempat dimensi yakni aktualisasi dari doktrin agama yang dihayati oleh seseorang yang berupa sikap, ucapan, dan perilaku atau tindakan. Dimensi konsekuensi ini mestinya merupakan kulminasi dari dimensi lain. Kenyataannya dimensi itu tidak selalu lengkap ada pada seseorang, sedangkan sikap, ucapan dan tindakan seseorang tidak selalu atas dorongan ajaran Agama ${ }^{1}$.

Berpegang pada pengertian religiusitas tersebut, dapat kita gambarkan kualitas keberagamaan bangsa kita. Contoh dari kalangan umat Islam misalnya, banyak yang belum memiliki dimensi religiusitas selengkapnya. Dalam terminologi Islam, mereka belum mencapai derajat muslim kaffah (seutuhnya). Contoh pertama, banyaknya orang yang rajin sholat, tetapi juga rajin membeli kupon judi togel, ada orang-orang yang ibadatnya rajin, tetapi mencari

1 Djamaludin Ancok dan Suroso, Psikologi Islam, 1994, hlm. 1-5. 
"Pesugihan"2 ke tempat-tempat keramat, minta pertolongan kepada jin, setan, tuyul dan lain-lain agar mereka menjadi orang kaya. Tidak sedikit orang berilmu Agama tinggi, tetapi mereka juga korupsi. Contoh lain, banyak orang kaya tetapi kikir dan tidak mau membantu meringankan penderitaan kaum fakir miskin, dan yang paling menjengkelkan lagi ada orang miskin dan marginal berlagak sombong dan semakin jauh dari norma - norma Agama. Contohcontoh tersebut menunjukkan kondisi religiusitas seseorang yang belum memiliki lima dimensi itu selengkapnya.

Perubahanyangkecenderungannya kearah positif yaitu dengan munculnya alat-alat teknologi modern yang dapat memudahkan manusia dalam menjalankan ibadah (ritual) dan mendekatkan dirinya kepada Yang Maha Kuasa, seperti contoh peran sarana transportasi dalam pelaksanaan ibadah haji dan lain sebagainya, serta semakin menambahkan keyakinan manusia akan keberadaan dan kebesaran Tuhan penguasa semesta alam, sehingga manusia semakin takut dan tambah taat dalam menjalankan kewajiban serta menjauhi segala larangannya. Namun disisi lain, perubahan tersebut juga memiliki kecenderungan kearah negatif pada sistem kapitalis liberal yang mana

2 Istilah yang berasal dari bahasa jawa yang artinya suatu aktifitas atau ritual untuk mencari kekayaan dengan cara memuja iblis atau makhluk ghoib melalui benda - benda yang dianggap keramat. seseorang merasa semakin hilangnya batas waktu (Borderlessworld) telah membuat kehidupan manusia semakin kompleks, perputaran waktu semakin cepat, sehingga orang merasakan terbatasnya waktu yang hanya tersedia 24 jam dalam sehari. ${ }^{3}$

Perubahan yang kecenderungannnya negatif pada tingkat religiusitas manusia, tidak menjalar disatu kalangan kaum intelektual yang menganut sistem kapitalis liberalis dan mendasarkan semuanya kepada ilmu pengetahuan (Sains) yang empiris saja, kecenderungan negatif tersebut juga menjalar kepada kaum marginal (mustadl'afin) yang notabenya bahwa mereka adalah korban dari semakin berkembangnya sains dan teknologi. Munculnya anggapan dari fenomena tersebut didasari kenyataan yang sering kali kita melihatnya disekitar masyarakatataulingkungankitasendiri pada khususnya, dan masyarakat Indonesia pada umumnya.

Melihat fenomena tingkat keberagamaan suatu masyarakat sangatlah menarik ketika dihubungkan dengan persoalan sosial yang lain, terutama pada masyarakat kota (urban community), di mana masyarakat kota lebih ditekankan pada sifat kehidupannya serta ciriciri kehidupannya yang berbeda dengan masyarakat pedesaan. Kehidupan keagamaan berkurang bila dibandingkan dengan kehidupan

3 Djamaludin Ancok, Pengantar Buku Psikologi Sholat, 2003. 
keagamaan di desa, karena orang kota pada umumnya dapat mengurus dirinya sendiri tanpa harus bergantung pada orang lain sehingga sangat individual. Contohnya masyarakat Lingkungan Dasan Cermen baik sebelah barat maupun timur, Kelurahan Dasan Cermen Kecamatan Sandubaya Kota Mataram, menjadi sangat unik bila diamati dan dicermati secara mendalam, disatu sisi berada diwilayah administratif Kota Mataram yang menjadi bagian dari komunitas masyarakatkota, namunsecarastruktur maupun kultur sosial masyarakat kota, perilakukeberagamaannya(religiusitas) sangat berbeda secara teoritis baik itu ciri maupun karakteristik masyarakat kota $^{4}$ yaitu : kehidupan keagamaan berkurang bila dibandingkan dengan kehidupan keagamaan di desa. Orang kota pada umumnya dapat mengurus dirinya sendiri tanpa harus bergantung pada orang lain.

Perilaku keberagamaannya (religiusitas) yang dimaksud disini adalah semangat keagamaannya masih sangat kuat, sistem kekerabatan dan keakrabannya masih terjaga dan semangat keberagamaan dan solidaritas membangun masjid sangat tinggi. Itulah sebabnya direncanakan untuk melakukan kajian dalam bentuk sebuah penelitian yang sangat terkait dengan hal tersebut di atas, dengan mengambil tema: Menakar Keberagamaan Masyarakat dan Solidaritas Membangun Masjid(Studi

4 Soejono Soekamto, Pengantar Sosiologi, (Surabaya: Erlangga, 2002), hlm. 313.
Kasus MasjidDarul Hidayah Kelurahan Dasan Cermen Kecamatan Sandubaya Kota Mataram).

\section{B. Pandangan Durkheim Tentang Sosiologi}

Dalam perspektif Durkheim secara umum bahwa yang paling fundamental yang mendasari pendekataan Durkheim terhadap sosiologi adalah bahwa gejala sosial itu riil dan mempengaruhi kesadaran individu serta perilakunya yang berbeda dari karakteristik psikologis, biologis, atau karakteristik individu lainnya. Lebih lagi karena gejala sosial merupakan fakta yang riil, gejala-gejala itu dapat dipelajari dengan metodemetode empirik yang memungkinkan satu ilmu sejati tentang masyarakat dapat dikembangkan. Dalam buku Durkheim yakni Rules, mendifinisikan fakta sosial sebagai cara-cara bertindak, berpikir dan merasa, yangberada diluar individu dan dimuati dengan sebuah kekuatan memaksa, yang karenanya hal-hal itu mengontrol individu. Fakta sosial bagi Durkheim, 'berada diluar' diri individu dalam arti bahwa fakta itu datang kepadanya dari diluar dirinya sendiri dan menguasai tingkah lakunya. ${ }^{5}$ Oleh karena itu, para ilmuan sosial pasti memperlakukan fakta sosial sebagai 'benda-benda' dengan cara yang sama seperti ilmuan-ilmuan alam memperlakukan objek-objek

5 Tom Campbel, Tujuh Teori Sosial, Terj. Budi Hardiman, (Yogyakarta: Kanisius, 2001), hlm. 168 . 
fisis yang kenyataannya harus mereka terima dan jelaskan.

\section{Karakteristik Fakta Sosial}

Bagaimana gejala sosial itu benarbenar dapat dibedakan dari gejala yang benar-benar individual? Durkheim mengemukakan dengan tegas tiga karakteristik yang berbeda: Pertama, gejala sosial bersifat eksternal terhadap individu. Karakteristik fakta sosial yang Kedua adalah bahwa fakta itu memaksa individu. Jelas bagi Durkheim bahwa individu dipaksa, di bimbing, di yakinkan, didorong atau dengan cara tertentu di pengaruhi oleh pelbagai tipe fakta sosial dalam lingkungan sosialnya. Karakteristik fakta sosial yang ketiga adalah bahwa fakta itu bersifat umum atau tersebar secara meluas dalam suatu masyarakat. Dengan kata lain, fakta sosial itu merupakan milik bersama bukan sifat individu perorangan. Sifat umumnya ini bukan sekedar hasil dari penjumlahan beberapa fakta individu. Fakta sosial benar-benar bersifat kolektif, dan pengaruhnya terhadap individu merupakan hasil dari sifat kolektifnya.

\section{Fakta Sosial Material dan Nonmaterial}

Durkheim membedakan dua tipe ranah fakta sosial, yaitu material dan nonmaterial. Fakta material diwakili oleh gaya arsitektur, bentuk teknologi, hukum dan perundang-undangan. Memang relatif mudah di pahami karena keduanya bisa diamati secara langsung. Durkheim mengakui bahwa fakta sosial nonmaterial memiliki batasan tertentu, ia ada dalam pikiran manusia. Akan tetapi dia yakin bahwa ketika orang memulai berinteraksi secara sempurna, maka interaksi itu akan mematuhi hukumnya sendiri. Durkheim membagi fakta sosial nonmaterial menjadi empat jenis; Moraitas, kesadaran kolektif, representasi kolektif dan arus sosial. Ada dua makna yang saling berkaitan dengan fakta-fakta sosial yakni bagian eksternal individu: (1) tiap orang dilahirkan dalam masyarakat yang terus berkembang dan yang telah memiliki suatu organisasi atau struktur yang pasti serta mempengaruhi kepribadiannya; (2) fakta-fakta sosial merupakan hal yang berada di luar bagi pribadi seseorang dalam arti bahwa setiap individu manapun, hanyalah merupakan suatu unsur tunggal dari totalitas pola hubungan yang membentuk suatu masyarakat. Penekanan dari tesis Durkheim ini adalah bahwa tidak ada satu teori atau analisis pun yang mulai dari individual, tak akan mampu memahami sifat-sifat spesifik dari fenomena sosial. Kriteria lain yang diterapkan Durkheim dalam menjelaskan sifat dari fakta-fakta sosial, merupakan kriteria yang empiris, yaitu hadirnya paksaan moral.

\section{Solidaritas Sosial Kehidupan Masyarakat}

Adapun yang berkaitan dengan solidaritas masyarakat Durkheim membagisolidaritasmenjadidua, yakni 
"solidaritas mekanik" dan "solidaritas organik". Dalam karya Durkheim Division of labor dapat digolongkan dalam Mazhab ini. Menurutnya unsur baku dalam masyarakat adalah faktor solidaritas. Dia membedakan antara masyarakat-masyarakat yang bercirikan faktor solidaritas mekanis dengan yang memiliki solidaritas organis. Pada masyarakat-masyarakat dengan solidaritas mekanis, warga masyarakat belum mempunyai diferensiasi dan pembagian kerja seperti masyarakat pedesaan yang kehidupan komunalnya masih solid yang dimana warga masyarakatnya mempunyai kepentingan bersama dan kesadaran yang sama pula. Sedangkan masyarakat dengan solidaritas organis memiliki ciri-ciri yakni telah mempunyai pembagian kerja yang ditandai dengan derajat spesialisasi tertentu, seperti spesialis mata, ginjal, jantung dan lain sebagainya ${ }^{6}$

Konsep-konsep dalam The Division of Labor di lanjutkan Durkheim dalam The Rules of Sociological Method (1895). Solidaritas sosial di pandang sebagai perpaduan kepercayaan dan perasaan yang di miliki para anggota suatu masyarakat tertentu. Rangkaian kepercayaan ini membentuk suatu sistem dan memiliki "ruh" tersendiri. Pada kajian lebih dalamnya, Durkheim mengemukakan pernyataan yang lebih meyakinkan mengenai hakikat faktafakta sosial dan juga menetapkan kriteria metode analisinya. Hasilnya

6 Tulisan ini dikutif dalam bentuk pdf dengan judul Teori-teori Sosiologi .pdf. adalah sebuah statemen terbaik untuk mengungkapkan positivistik yang di terapkan di zamannya. Prestasi lainnya adalah di perolehnya kepastian bahwa solidaritassosial harusdianalisissampai kebeberapaunsurkomponennya.

Berdasarkan analisis Durkheim, persoalan tentang solidaritas di kaitkan dengan sanksi yang di berikan kepada warga yang melanggar peraturan dalam masyarakat. Bagi Durkhem indikator yang paling jelas untuk solidaritas mekanis adalah ruang lingkup dan kerasnya hukum-hukum dalam masyarakat yang bersifat menekan (represif). Hukum-hukum ini mendefinisikan setiap perilaku penyimpangan sebagai sesuatu yang bertentangan dengan nilai serta mengancam kesadaran kolektif masyarakat. Hukuman represif tersebut sekaligus bentuk pelanggaran moral oleh individu maupun kelompok terhadap keteraturan sosial (social order). Sanksi dalam masyarakat dengan solidaritas mekanis tidak di maksudkan sebagai suatu proses yang rasional. Hukuman tidak harus merepresentasikan pertimbangan rasional dalam masyarakat. Hukum represif dalam masyarakat mekanis tidak termasuk pertimbangan yang di berikan yang sesuai dengan bentuk pelanggarannya. Sanksi atau hukuman yang di kenakan kepada orang yang menyimpang dari keteraturan, tidak lain merupakan bentuk atau wujud kesadaran kolektif masyarakat terhadap tindakan individu tersebut. Pelanggaran terhadap kesadaran 
kolektif merupakan bentuk penyimpangan dari homogenitas dalam masyarakat karena dalam analisis Durkheim, cirikhas yang paling penting dari solidaritas mekanis itu terletak pada tingkathomogenitas yang tinggi dalam kepercayaan, sentimen, dan sebagainya. Homogenitas serupa itu hanya mungkin kalau pembagian kerja (division of labor) bersifat terbatas.

Model solidaritas seperti ini biasa di temukan dalam masyarakat primitif atau masyarakat tradisional yang masih sederhana. Dalam masyarakat seperti ini pembagian kerja hampir tidak terjadi. Seluruh kehidupan di pusatkan pada sosok kepala suku. Pengelolaan kepentingan kehidupan sosial bersifat personal. Keterikatan sosial terjadi karena kepatuhan terhadap nilai-nilai tradisional yang dianut oleh masyarakat. Demikian juga sistem kepemimpinan yang di laksanakan berjalan secara turuntemurun. Potret solidaritas sosial dalam konteks masyarakat dapat muncul dalam berbagai kategori atas dasarkarakteristik sifat atau unsuryang membentuk solidaritas itu sendiri. mengutip pendapat Durkheim yang membedakan solidaritas sosial dalam dua kategori.

Solidaritas mekanis ini, terjadi dalam masyarakat yang memiliki ciri khas keseragaman pola-pola relasi sosial, memiliki latar belakang pekerjaan yang sama dan kedudukan semua anggota. Apabila nilai-nilai budaya yang melandasi relasi mereka, dapat menyatukan mereka secara menyeluruh maka akan memunculkan ikatan sosial yang kuat dan di tandai dengan munculnya identitas sosial yang kuat pula. Individu menyatukan diri dalam kebersamaan, sehingga tidak ada aspek kehidupan yang tidak diseragamkan oleh relasi-relasi sosial yang sama. Individu melibatkan diri secara penuh dalam kebersamaan pada masyarakat. Karena itu, tidak terbayangkan bahwa hidup mereka masih dapat berlangsung apabila salah satu aspek kehidupan di pisahkan dari kebersamaan.

Solidaritas mekanis menunjukkan berbagai komponen atau indikator penting. Contohnya yaitu, adanya kesadaran kolektif yang di dasarkan pada sifat ketergantungan individu yang memiliki kepercayaan dan pola normatif yang sama. Individualitas tidak berkembang karena di hilangkan oleh tekanan aturan atau hukum yang bersifat represif. Sifat hukuman cenderung mencerminkan dan menyatakan kemarahan kolektif yang muncul atas penyimpangan atau pelanggaran kesadaran kolektif dalam kelompok sosialnya.

Singkatnya, solidaritas mekanis di dasarkan pada suatu "kesadaran kolektif" (collective consciousness) yang di lakukan masyarakat dalam bentuk kepercayaan dan sentimen total di antara para warga masyarakat. Individu dalam masyarakat seperti ini cenderunghomogen dalam banyakhal. Keseragaman tersebut berlangsung terjadidalam seluruh aspek kehidupan, 
baik sosial, politik bahkan kepercayaan atau agama. $^{7}$

Solidaritas organis terjadi $\mathrm{di}$ masyarakat yang relatif kompleks dalam kehidupan sosialnya namun terdapat kepentingan bersama atas dasar tertentu. Pada kelompok sosialnya, terdapat ciri-ciri tertentu, yaitu :

a) Adanya pola antar-relasi yang parsial dan fungsional

b) Terdapat pembagian kerja yang spesifik,

c) Adanya perbedaan kepentingan, status, pemikiran dan sebagainya.

Perbedaan pola relasi-relasi dapat membentukikatansosialdan persatuan melaluipemikiran yang membutuhkan kebersamaan serta diikat dengan kaidah moral, norma, undangundang, atau seperangkat nilai yang bersifat universal. Karena itu, ikatan solidaritas tidak lagi menyeluruh, melainkan terbatas pada kepentingan bersama yang bersifat parsial. Solidaritas organis muncul karena pembagian kerja bertambah besar. Solidaritas ini di dasarkan pada tingkat saling ketergantungan yang tinggi. Ketergantungan ini di akibatakan karena spesialisasi yang tinggi di antara keahlian individu. Spesialisasi ini juga sekaligus mengurangi kesadaran kolektif yang ada dalam

7 http://inifanfan.blogspot. co.id/2013/09/sosiologi-klasik-solidaritassosial $3514 . \mathrm{html}$. masyarakat mekanis. Akibatnya, kesadaran dan homogenitas dalam kehiduan sosial tergeser. Keahlian yang berbeda dan spesialisasi itu, munculah ketergantungan fungsional yang bertambah antara individuidividu yang memiliki spesialisasi dan secara relatif lebih otonom sifatnya. Menurut Durkheim itulah pembagian kerja yang mengambil alih peran yang semula di dasarkan oleh kesadaran kolektif.

\section{Sistem Sosial Keagamaan Masyarakat Dasan Cermen}

Sistem sosial keagamaan masyarakat dasan cermen bisa dikatakan unik, karena dasan cermen merupakah daerah perkotaan. Keunikan Dasan Cermen ini karena memiliki perbedaan yang menonjol di antara kota provinsi lainnya di seluruh Indonesia, di mana modernisasi memaksa orang-orang desa bermigrasi mencari kerja ke kota sehingga menciptakan masyarakat urban perkotaan. Analisis Dukheim tentang solidaritas mekanik terjadi pada masyarakat perkotaan ini, mereka menciptakaan aturan-aturan baru (fakta sosial) demi menstabilkan hubungan sosial di antara mereka. Dalam arti lain semakin kota masyarakat tersebut maka semakin lunturagama dan budaya mereka. Lima tahun terakhir, geliat pembangunan kota Mataram begitu pesat menarik para pencari pekerjaan berbondongbondong ke kota Mataram, selain mengadu nasip mencari kerja, sembari 
menetap juga menyekolahkan anakanak mereka mulai dari TK hingga pergururan tinggi.

Setiap daerah di kota Mataram selain orang pribumi (sasak) juga diisi oleh para pendatang yang mencoba mengadu nasip, tak terkecuali di kelurahan Dasan Cermen tempat penelitianinidilaksanakan. Masyarakat Dasan Cermen adalah bagian dari kota Mataram, meskipun modernisasi berdampak pada hubungan sosial yang semakin individualis namunlain halnya dengan masyarakat Dasan Cermen. Masyarakat dengan budaya kesasakan mereka (dominasi mayoritas) menjadi alat perekat pemersatu di antara mereka, tradisi begawe banjar sebagaimana berlaku pada masyarakat pedesaaan juga masih berlaku pada masyarakat dasan cermen, tradisi nyongkolan selalu dilaksanakan tatkala anggota masyarakatnya melakukan pernikahan, nyunatan, ngurisan, salingjot (Islam dan Hindu). Untuk mempererat tali silaturrahmi beberapa warga kelurahan Dasan Cermen mengadakan yasinan sekali dalam satu minggu baik diikuti oleh para pemuda maupun orang tua. Pengajian bulanan juga kerapkali diselenggarakan oleh warga Dasan Cermen di masjid timur maupun di barat, penceramahnya terkadang diundang dari berbagai pondok pesantren. selain pengajian di masjid terdapat juga pengajian yang diselenggarakan oleh ustadz Saheb yang jamaahnya merupakan warga setempat, juga berdatangan dari berbagai wilayah di luar Dasan Cermen lainnya.

Adapun yang berkaitan dengan organisasi keagamaan yang ada di Dasan Cermen, sama halnya juga seperti organisasi keagamaan lain yang ada di Indonesia, seperti Muhammadiyah dan NU. Adapun organisasi peninggalan orang pribumi sasak yakni Nahdlatul Wathan telah mengambil peran yang sangat besar terhadap pengembangan kualitas ummat di Lombok. baik kualitas spiritual, ekonomi, sosial, pendidikan dan kualitas budaya. ${ }^{8}$ Perkembangan pesat kota Mataram menjadi sebuah kota dengan berbagai peluang yang tersedia cukup menjanjikan, yang menjadikannya magnet bagi warga masyarakat dari berbagai wilayah, baik yang berasal dari desa yang ada dalam wilayah Kabupaten-kabupaten yang ada di wilayah Provinsi Nusa Tenggara Barat (pulau Lombok sendiri maupun pulau Sumbawa), hal demikian juga menarik minat warga dari provinsiprovinsi tetangga, seperti pulau Bali, Sumatra, Jawa, Kalimantan, dan lainlain sebagaimana berlaku juga di kotakota lainnya semisal kota Pangkalan Kerinci. ${ }^{9}$

8 Baharuddin, "Nahdlatul Wathan dan Perubahan sosial", (Skolah Tinggi ilmu Tarbiyah Nurul Hakim Kediri Lombok Barat, Yogyakarta Genta Press, 2007), hlm. 8.

9 Perbedaan sistem nilai budaya masyarakat desa (rural society) dengan sistem nilai budaya masyarakat kota (urban society) yang kontras menimbulkan masalah sendiri bagi warga masyarakat desa yang berurbanisasi, Hidayat Syah, "Urbanisasi dan Modernisasi Studi Tentang Perubahan Sistem Nilai Budaya Masyarakat Urban di Pangkalan Kerinci 
Biasanya disetiapkota-kotaprovinsi fenomena asimilasi terjadi, asimilasi di sinimaksudnyaadalahprosessosialyang terjadi memungkinkan komunitaskomunitas dengan keragaman budayaan, saling berinteraksi satu sama lainnya untuk waktu yang begitu lama sehingga mengasilkan bebudayaan campuran. Namun di Dasan Cermen proses penyesuaian kebudayaan lama lebih menonjol di akibatkan oleh kebudayaan pribumi yang dominan. Proses penyesuaian diri di antara kebudayaan pribumi yang berbeda darinya yang menghasilkan pola kehidupan yang memiliki keserasian fungsi. Mereka beradaptasi dan bersikap kompormis terhadap budaya masyarakat Dasan Cermen (sasak) melahirkan harmonisasi dalam bermasyarakat, tidak pernah terjadi konflik antar masyarakat bahkan meskipun Dasan Cermen termasuk Kota Mataram namun solidaritas mekanik lebih menonjol terbukti ketika pembangunan masjid. Kegiatan makan bersama tradisi (Begibung) yang mana semua orang duduk sejajar tanpa membedakan setatus sosial masih dipraktikkan oleh masyarakat Dasan Cermen. Saling menghormati tradisi antar masyarakat muslim dan masyarakat hindu di kelurahan Dasan Cermen sebagaimana pak Udin sampaikan:

$$
\begin{array}{lrc}
\text {.....selama mereka sopan dan } \\
\text { menghargai tradisi budaya dan }
\end{array}
$$

Kabupaten Pelalawan”, dalamJurnal Toleransi, Vol. 5 No. 1 Januari - Juni 2013. keagamaan masyarakat mayoritas, saya rasa tidak akan pernah terjadi konflik. ${ }^{10}$

Beliau juga menajelaskan sikap saling menghormati telah lama dipupuk oleh warga masyarakat dasan cermen, baik warga pendatang dengan budaya yang mereka bawa, juga oleh warga dasan cermen asli. Salah satu contohnya adalah ketika ada rombongan pengantin yang diiringi gambelan melewati komunitas Hindu, maka orang-orang Islam akan menghentikan tabuhan gambelan gendang belek tanpa ada suara dan teriakan. Hal sebaliknya juga berlaku kepada komunitas Hindu, ketika mereka mengadakan ritual yang ada tabuhannya seperti ngaben, pejagraya ketika melewati komunitas muslim maka seketika itu tabuhan gambelan itu dihentikan.

Di Dasan Cermen juga terdapat tradisi saling pelangarin antar warga berbeda budaya. Pelangarin dalam bahasa sasak berarti saling melayat ketika salah satu warga Dasan Cermen meninggal mereka berbondongbondong memberikan bantuan motivasi kepada pihak keluarga yang ditinggal mati, mengunjungi sebagai bentuk persaudaraan baik yang beragama berbeda maupun budaya yang berbeda.

......Kami memang biasa melakukan hal tersebut, kami melayat ke keluarga cina, hindu, orang jawa, orang sumatra dan

10 Wawancara dengan Pak Udin 45 Tahun, Tanggal 5 September 2016. 
lain-lain itu sudah menjadi kebiasaan yang terpatri sejak lama. Saya tidak tahu kapan dimulai. ${ }^{11}$

Berkaitandenganitu, adapun proses asimilasi yang terjadi pada masyarakat Lombok terutama pada masyarakat Dasan Cermen, alangkah baiknya mengupas sedikit proses masuknya Islam di NTB. Islam masuk di daerah NTB sekitar tahun 1521 Masehi. Pada masa kerajaan Demak yang dibawa oleh Sunan Prapen Putra dari Sunan Giri pada masa Kolonial Belanda ke 20 ini memiliki pemerintahan yang terpisah yaitu Pulau Lombok yang dikuasai oleh kerajaan Hindu Bali, sementara pulau Sumbawa dibawah kesultanan Sumba dan Bima. Mayoritas penduduk kelurahan Dasan Cermen yaitu beragama Islam di mana total penduduk yang beragama Islam yaitu sebanyak 2.104 orang laki-laki dan 2.085 orang perempuan, kemudian Budha sebanyak 87 orang, beragama Hindu 48 orang Kristen 28 orang dan beragama Katolik 3 orang. Secara mayoritas Masyarakat Dasan Cermen setelah masuk Islam, pada mulanya adalah penganut wetutelu, sebagaimana amak Anom mengatakan:

......dahulu masyarakat dasan cermen adalah penganut wetu telu, mereka orang-orang tua kita dulu jarang sholat, namun ketika beberapa diantara mereka memondokkan anak-anak mereka yang

11 Wawancara dengan Amaq Burhan 50 Tahun, Tanggal 12 Agustus 2016. sekarang menjadi ustadz di lingkungan ini menjadi penganut waktu lima. ${ }^{12}$

Tampak ritual-ritual keagamaan yangmiriphindujugaikutberakulturasi ke dalam tindakan masyarakat dasan cermen waktu itu. Islam semakin diminati oleh masyarakat setempat setelah tokoh-tokoh Agama (UstadzUstadz yang berafiliasi organisasi NU dan NW) dengan corak tradisi pedesaan dibawa pulang oleh para santri yang telah mondok sekian lama dan sudah siap untuk berdakwah. Masyarakat Dasan Cermen hari ini meskipun merupakan kelurahan yang masuk dalam kecamatan Sandubaya Kota Mataram namun masih memiliki solidaritas mekanik yang sangat kuat. Persatuan dan kesatuan terhadap kelompok tergambar tatkala membangun masjid.

\section{Pemahaman Agama Masyarakat Dasan Cermen}

Pemahaman keberagamaan masyarakat Dasan Cermen tentu dapat dilihat dari beberapa interkasi yang terbangun. Interkasi antara manusia dengan Tuhan adalah interkasi perhambaan yang ditandai dengan adanya ketaatan, kepatuhan, dan penyerahan diri kepada Tuhan. Ketaatan dan kepatuhan kepada Tuhan diawali dengan pengakuan dan keyakinan akan kemahakuasaanNya. Keyakinan itu akan mendorong untuk mewujudkannya dalam tingkah

12 Wawancara dengan Pak Anom 50 Tahun, Tanggal 12 September 2016. 
laku, berupa taat dan patuh kepada semua aturan yang telah digariskan Tuhan. Ketaatan dan kepatuhan yang didasarkan atas keyakinan akan melahirkan ketenangan batin dan keikhlasan.

\section{Dimensi Interakasi Ketuhanan}

Manusia merupakan ciptaan Tuhan untuk selalu mengabdikan hidupnya kepada Tuhan, karena manusia diciptakan oleh Tuhan, maka hidupnya selalu berorentasi untuk mengarahkan hidupnya kepada sang pencipta. Sang pencipta yang memberikan hidup, menumbuhkan dan mengembangkan manusia, maka manusia harus selalu beribadah kepada penciptanya. ${ }^{13}$ Interaksi antara manusia dengan sang penciptanya dapat dilihat dari kemurahan Tuhan melayani manusia, apabila Tuhan maha pemurah melayani manusia maka manusia hendaknya selalu murah dan berdzikir kepadanya. ${ }^{14}$ Manusia sebagai makhluk yang berpikir dan merasa serta berkehendak dimana perilakunya mencerminkan apa yang dipikir, yang dirasa dan yang dikehendakinya. Di samping ia dapat menghayati perasaan keislaman dirinya ia juga dapat meneliti keberislaman orang lain. Islam tentu

13 Taufik Adnan Amal, Rekonstruksi Sejarah Al-Qur'an, (Yogyakarta: Pustaka Pelajar, 2001), hlm. 1-5.

14 Ahmad Chodjin, Jalan Pencerahan, (Jakarta: PT Serambi Ilmu Semesta, 2002), hlm 119. menjamin juga hubungan antara sang pencipta dan manusia. ${ }^{15}$

Dimensi Interkasi masyarakat Dasan Cermen dengan Tuhan tentu dapat dilihat dari beberapa indikator. Pertama intensitas dalam melaksanakan solat; solat pada dasarnya terbagi menjadi dua meliputi sholat fardhu dan sholat sunnah. Sholat fardu merupakan sholat wajib yang dikerjakan seorang muslim sebanyak lima kali dalam sehari, disampingbanyaksholat-sholat sunnah lainnya. intensitas pelaksanaan solat masyarakat dasan cermen dapat dikatakan aktif berdasarkan usia. Dimana dalam intensitas sholat dapat dibagi menjadi tiga tempat. Pertama berjamaah di masjid, untuk siang hari yakni pada sholat zuhur dan ashar, umumnya lebih dominan para ibu rumah tangga, orangtua serta pendatangyangsinggahdariperjalanan. Kedua di rumah masing-masing yang umumnya dilaksanakan oleh warga yang berprofesi sebagai pedagang dan petani. Ketiga dilaksanakan pada lokasi kerja pada umumnya oleh para buruh, dan pegawai pemerintahan. Adapun wawancara yang dilakukan dengan bapak Andi mengatakan:

......Pelaksanaan solat fardumemang wajib bagi semua umat Islam, akan tetapi masyarakat desa kami yang rutin melaksanakan solat yakni para orangtua dan anak-anak, sedangkan para pemudanya jarang, hal ini mungkin dikarenakan jiwa muda yang masih

15 Nina W. Syam, Sosial Sebagai Akar Ilmu Komunikasi, (Badung: Simbiosa Rekatama Media, 2012), hlm. 209. 
senang-senang, dan ditambah lagidengan gaya hidup sekarang menyebabkan para pemuda di dasan cermen jarang untuk melaksanakan solat berjamah di masjid. ${ }^{16}$

Kedua, Intensitas dalam melaksanakan ibadah puasa; seperti solat, begitu pula dengan ibadah puasa pada dasarnya terbagi menjadi dua yakni; puasa wajib dan sunnah. Puasa wajib salah satunya puasa ramadan yang dilaksanakan satu bulan penuh dalam satu tahun sekali yakni pada bulan ramadhan, disamping ada puasa wajib karena memenuhi nadzar ${ }^{17}$. Pelaksanaan puasa mungkin bagi orang yang tidak terbiasa, ibadah ini merupakan ibadah yang paling berat apalagi bagi mereka dalam kondisi dan profesi tertentu. Meskipun masyarakat Dasan Cermen adalah masyarakat kota, akan tetapi intensitas dalam melaksanakan puasa tercermin dari sikap, mental serta budaya setempat yangselalumenjagakepercayaanbahwa berpuasa sebulan penuh harus tetap dilaksanakan, karena itu perintah dari Tuhan untuk melaksanakannya. Dari wawancara yang dilakukan peneliti dengan seorang warga dasan cermen Syamsul Hadi mengungkapakan:

.....Berpuasa merupakan kewajiban bagi kita semua, meskipun tempat tinggal saya adalah kota akan tetapi yang berkaitan dengan ibadah puasa

16 Wawancara dengan Bapak Andi 40 Tahun, Tanggal 19 Agustus 2016.

17 Nadzar merupakan sikap, keinginan, hutang ataupun janji kepada diri sendiri untuk melaksanakan urusan pribadi. saya tetap menjalankannya, karena tempat tinggal saya kalau sudah bulan puasa datang semua penjual makanan, warung nasi semua harus libur untuk menghormati masyarakat yang puasa. ${ }^{18}$

Ketiga, pelaksanaan ibadah haji merupakan suatu kenikmatan dan keberkahan tersendiri bagi umat muslim yang melaksanakannya, apalagi ibadah haji merupakan bagian dari rukun islam. Ibadah haji merupakan cita-cita semua umat islam di muka bumi ini, tidak terkecuali juga masyarakat dasan cermen. Ibadah haji bagi masyarakat dasan cermen adalah keunggulan tersendiri, yakni unggul dalam hal materi, karena menurut masyarakat dasan cermen bapak Hanan mengungkapakan:

\section{.....Ibadahhajimemangsuatukewajiban bagi orang yang mampu, akan tetapi haji bagi saya yang belum berhaji selalu menjadi perlombaan, yakni berlomba- lomba untuk melaksanakannya. Masyarakat kami sudah banyak yang pergi berhaji dan saya melihatnya sebagai ajang perlombaan untuk melaksanakannya. Dan rata-rata yang melaksanakan haji di desa kami memiliki tingkat ekonomi yang tinggi, apalagi haji dalam pandangan masyarakat kami merupakan status yang sangat tinggi. ${ }^{19}$}

Disamping itu juga interaksi ketuhanan masyarakat Dasan Cermen dapat dilihat dari keberadaan aliran tariqat. Dan tariqat ini bagi masyarakat

18 Wawancara dengan Syamsul Hadi 27 Tahun, Tanggal 3 September 2016.

19 Wawancara dengan Bapak Hanan 43 Tahun, Tanggal 10 September 2016. 
Dasan Cermen merupakan ritual tertinggi untuk berinteraksi dengan Tuhan. Keberadaan tariqat di Dasan Cermen tentu tidak bisa lepas dari term tasawuf. Konsep tasawuf sendiri sudah menjadi disiplin keilmuan, yakni sebagai suatu kajian mengenai cara dan jalan yang dilakukan seseorang muslim untuk senantiasa berdekatan dan bermunjat kepada Tuhan, karena syarat yang utama untuk berdekatan dengan tuhan itu membutuhkan kesucian jiwa, mental dan spiritual yang tinggi dan selalu ditempuh pada ajaran-ajaran Islam. Tasawuf menurut Muhammad Abdul Haq Ansari dalam abu '1-husayn '1-Nuri tasawuf is neither external action (rasm) or knowledge (ilm), its all virtue (khulq). Sedangkan menurut junaydtasawwuf is that your devotion to god is not for any other purpose. ${ }^{20}$

In other definition of tasawwuf al-malibary says taht tasawwuf is tantamount to adab (good behaviour education). Sedangkan menurut Nawawi tasawwuf means altogether godd behaviour. He adds however another definition; tasawwuf signifies the emptying of the heart of all things except god and having contempt for everything else. ${ }^{21}$

Apabila dilihat intensitas pelaksanaan ritual keagamaan seperti

20 Muhammad Abdul Haq Ansari, Sufism And Shari'ah, A Study of Shaykh Ahmad Sirhindi's Effort To Reform Sufism, (London: The Islamic Foundation, 1986), hlm. 31.

21 Sri Mulyati, Sufism In Indonesia: An Anlysis Of Nawawi Al-Banteni's Salim Al-Fudala, (Institute of Islamic Studies McGill University Montreal. P.Q Canada, 1992), hlm. 59. sholat, puasa, haji, dan ditambah dengan keberadaan tariqat bahwa masyarakat dasan cermen memiliki tingkat keberagamaan yang tinggi serta solidaritasnya sangat terbangun sehingga dalam pemahaman dan penghayatan tentang doktrin-doktrin ajaran keagamaan sudah tertanam pada masyarakat Dasan Cermen. Dari beberapa hasil wawancara serta pernyataan di atas, bahwa masyarakat Dasan Cermen memiliki tingkat keberagamaaan yang tinggi sehingga sangat berpengaruh terhadap solidaritas pembangunan masjid.

Adapun tariqat yang di anut oleh masyarakat Dasan Cermen yakni Qodariyah. Tarekat qodariyah ini pada dasarnyaberangkatdariseorangulama' besar yakni Abdul Qadir dari Gilan, yang lahir di Nif, distrik Gilan, sebelah selatan Laut Kaspia. Dia meninggal dunia pada 1166, dan menggunakan terminologi sangat sederhana yang kemudian hari digunakan oleh orangorang Rosicrucia di Eropa. Hadrat Syekh Abdul Qadir, khususnya dalam pengaruhnya terhadap keadaankeadaan spiritual, disebut 'Ilmu Pengetahuan Keadaan. Pekerjaannya telah digambarkan dalam istilah yang berlebih-lebihan oleh para pengikutnya. Semangat untuk mengerjakan yangberlebihan terhadap teknik-teknik menggembirakan hampir pasti menjadi sebab keadaan yang memburuk dari tarekat Qadiriyah. Hal ini mengikuti suatu pola umum dalam diri para pengikut, apabila hasil dari suatu kondisi pikiran 
yang berubah menjadi suatu tujuan dan bukan suatu cara atau alat yang diawasi oleh seorang ahli. Keberadaan tariqat di Indonesia tentu tidak lepas dari sejarah panjang. Di Indonesia sendiri perkembangan tariqat bisa dikatakan sangat pesat sekali. Islam yang datang ke nusantara melalui transportasi laut harus menyusuri pantai Laut Merah, negeri Yaman, Hadramaut, Gujarat, Pulau Seylon (Sri Lanka), mungkin teluk Benggala, selanjutnya sampai Pattani Thailand Selatan, baru sampai di Perlak. Dari Perlak menyusuri Banten, Gresik terus ke timur melalui Mataram (Lombok) ke Maluku, tempat-tempat itu masingmasing mempunyai peranan dalan perkembangan Islam. ${ }^{22}$

Keberadaan tariqat yang ada di dasan cermen tentu sangat menunjang tingkat religiusitas masyarakat dasan cermen sebagai manifestasi interaksi terhadapketuhanan. Keeradaan tariqat ini sebagai simbol bahwa masyarakat Dasan Cermen memiliki tingkat religiusitas yang cukup tingga sebagai basis solidaritas dalam membangun masjid, karena masjid sebagai tempat mereka melakukan ibadah serta ritualritual keagamaan.

22 Untuk penjelasan teori-teori masuknya Islam di Nusantara (termasuk di jawa) dapat di lacak beberapa buku, misalnya T.W. Arnold, The Preaching of Islam: A History of The Propagation of The Muslim Faith (lahore SA Muhammad Asraf, 1968), hlm. 369, Tan Sen, Cheng Ho: Penyebar Islam dari China ke Nusantara, (Jakarta: Penerbit Buku KOMPAS 2010); John Bastin dan Jullian Benda ,A History of Modern Southeast Asia (New Jersey: Prentice, 1968). hlm. 6-15.

\section{Dimensi}

Interakasi

\section{Kemanusiaan}

Disamping interkasi manusia dengan Tuhan, interaksi manusia dengan sesama juga penting, hal ini bisa dilihat dari kebiasaan masyarakat Dasan Cermen saling berinterkasi, akan tetapi wadah yang paling efektif bagi masyarakat Dasan Cermen untuk berinterkasi yakni di masjid sekaligus mereka bisa saling silaturrahmi. Sebagai mahluk sosial manusia tidak bisa lepas dari mahluk lain, dan membutuhkan interaksi dengan orang lain. Manusia membutuhkan untuk berkomunikasi dan berinterkasi, karena interkasi menjadi suatu keharusan dalam kehidupan, karena dari interkasiakan terbangun dialog sebagai arena untuk berbagi dan bertukar makna. Apa tujuan dialog; adalah dialog itu sendiri, karena dalam perspektif sistem, komunikasiberperan sebagai tujuan, bukan sebagai sarana, apabila komunikasi menjadi sarana maka semua elemen yang terdapat didalamnya adalah sarana, akan tetapi komunikasi adalah tujuan untuk berdialog, adanya dialog/komunikasi sebagai tujuan guna membangun interkoneksi antar komponen untuk memulai dan mempertahankan identitas atau keberadaanya sebagai sistim sosial. Setiap komunikasi adalah untuk mencari kebenaran yang lebih tinggi.Kebenaran yangdimaksud adalah kebenaran intersubyektif yang merupakan indikasi dari dialog, adanya dialog ini menyaratkan keterbukaan, keberterimaan dan melahirkan 
tindakan bersama collective action. Tujuan lain dilakukannya dialog adalah untuk menciptakan kesadaran intersubyektif yang bersifat nonmaterial, karena selama ini yang sering terjadi dalam kehidupan manusia selalu mereduksi manusia dengan materi, sehingga manusia dipandang sebagai obyek semata, sehingga tidak ada penghargaan manusia sebagai mahkluk yang memiliki dignity. ${ }^{23}$

Sebagai umat beragama, setiap orang harus menjalin hubungan baik antar sesamanya setelah menjalin hubungan baik dengan Tuhannya. Dalam kenyataannya sering kita saksikan dua hubungan ini tidak padu. Terkadang ada seseorang yang dapat menjalin hubungan baik dengan Tuhannya, tetapi ia bermasalah dalam menjalin hubungan dengan sesamanya. Atau sebaliknya, ada orang yang dapat menjalin hubungan secara baik dengan sesamanya, tetapi ia mengabaikan hubungannya dengan Tuhannya. Tentu saja kedua contoh ini tidak benar. Yang seharusnya dilakukan adalah bagaimana ia dapat menjalin dua bentuk hubungan itu dengan baik, sehingga terjadi keharmonisan dalam dirinya. Pada prinsipnya ada tiga bahasan pokok terkait dengan pembinaan akhlak mulia dalam berhubungan antar sesama manusia ini. Bahasan pertama terkait dengan akhlak manusia terhadap diri sendiri. Akhlak ini bertujuan untuk membekali

23 Ishak Hariyanto, Meniti Renaisans Lewat Pembelajaran Rekognitif Di Lombok. Buku ini dalam proses penerbitan, (Mataram: Sanabil Press), hlm. 95. manusia dalam bereksistensi diri di hadapan orang lain dan terutama di hadapan Tuhan Swt. Bahasan kedua terkait dengan akhlak manusia dalam kehidupan keluarganya. Akhlak ini bertujuan membekali manusia dalam hidup di tengah-tengah keluarga dalam posisinya masing-masing. Dan bahasan ketiga terkait dengan akhlak manusia dalam kehidupan bermasyarakat. Akhlak ini membekali manusia bagaiman bisa berkiprah di tengah-tengah masyarakatnya dengan baik dan tetap berpegang pada nilainilai akhlak yang sudah digariskan oleh ajaran Islam. ${ }^{24}$ Apabila dilihat dari perspektif sosiologi, bahwa manusia tidak bisa terlepas dari hubungannya dengan orang lain, dan memiliki ciriciri kepribadian sebagia berikut:

a. berkarya dan menyumbang serta mau memberi dan menerima

b. memandang baik diri sendiri dan orang lain

c. memenuhi kebutuhan sendiri tanpa harus mengganggu atau mengorbankan orang lain.

\section{Dimensi Interakasi Lingkungan}

Manusia adalah makhluk yang berpikir danmerasa serta berkehendak dimana perilakunya mencerminkan apa yang dipikir, yang dirasa dan yang dikehendakinya. Pribadi yang mampu mengatur diri di dalam

24 Marzuki, Pembinaan Akhlak Mulia Dalam Hubungan Antar Manusia Dalam Perspektif Islam, tulisan ini disadur dalam bentuk pdf, hlm. 9. 
hubungannya dengan lingkungan dan dapat menciptakan serta mengolah lingkungannya dengan baik. ${ }^{25}$ Manusia dapat pula mempengaruhi alam sebagaimana alam mempengaruhi manusia. Ketika alam membentuk perilaku manusia maka manusiapun dapat membentuk perilaku alam di luar konteks kebiasaannya. Manusia dengan segala perilakunya merusak alam dan menciptakan banjir di lingkungan tempat tinggalnya dan secara sebaliknya banjir yang rutin terjadi membentuk perilaku yang khas dari mereka yang tinggal di kawasan tersebut dibandingkan mereka yang tinggal di kawasan bebas banjir. Sebuah contoh sederhana ini mungkin akan menjadi langkah awal yang baik untuk merenungi bagian selanjutnya dari tulisan ini. ${ }^{26}$

Berkaitan dengan konteks lingkungan, sebagian orang masih belum banyak mengenal environmental personality yang dikembangkan oleh McKechnie dalam Wahyu Raharjo menjabarkan beberapa klasifikasi tipe manusia berkepribadian lingkungan, yaitu :

a. Pastoralism di mana individu yang memiliki poin tinggi di sini adalah individu yang suka menentang penggunaan dan

25 Nina W. Syam, Sosial Sebagai Akar Ilmu Komunikasi, (Badung: Simbiosa Rekatama Media, 2012), hlm. 208.

26 Wahyu Rahardjo, "Hubungan ManusiaLingkungan: Sebuah Refleksi Singkat” dalam JurnalPenelitian Psikologi, (Fakultas Psikologi Universitas Gunadarma no. 2, vol. 11, Desember 2006), hlm. 160 . pengembangan lahan secara salah dan semena-mena tanpa memperhatikan keseimbangan eksosistem dan dampaknya terhadap lingkungan.

b. Urbanism di mana individu yang tergolong dalam kategori ini adalah mereka yang mampu menikmati lingkungan dengan kepadatan tinggi dan sangat menghargai keragaman stimulasi antar pribadi dan budaya salam kehidupan kota.

c. Environmental adaptation di mana individu yang tergolong dalam kategori ini adalah merekayangsecarabaikmampu melakukan pengurangan ketidaksesuaian kebutuhan sebagai manusia dengan keadaan yang ada dengan merubah lingkungannya.

d. Stimulus seeking di mana individu yang tergolong dalam kategori ini adalah mereka yang memiliki kecenderungan suka bersenang-senang dan melakukan eksplorasi alam dan sangat menikmati sensasi fisik yang sifatnya intens dan kompleks yang di dapat dari kegemarannya melakukan perjalanan dan petualangan.

e. Environmental trust di mana individu yang tergolong dalam kategori ini adalah mereka yang memiliki kecenderungan untuk mampu percaya pada 
suatu lingkungan, tidak takut dengan lingkungan baru dan tidak takut menjadi sendiri dalam lingkungan tersebut.

f. Antiquarianism dimanaindividu yang tergolong dalam kategori ini adalah mereka yang begitu menikmati perjalanan dan kunjungan ke tampat-tenpat bersejarah, tempat-tempat dengan desain tradisional dan menghargai produk-produk dari masa lampau.

g. Need for privacy di mana individu yang memiliki poin tinggi pada kategori ini adalah mereka yang memiliki kecenderungan untuk sering membutuhkan keadaan lingkungan yang tenang, suka beradadalamkeadaanterisolasi, menghindari gangguan dan mencari kesendirian.

h. Mechanical orientation di mana individu yang tergolong dalam kategori ini adalah mereka yang suka menikmati proses mekanis dan teknologi, senang menghandle segala sesuatunya sendiritanpabantuan oranglain dan sangat peduli terhadap cara kerja sesuatu hal atau benda yang menarik perhatiannya.

Di samping beberapa penjelasan di atas, Sonnenfeld dalam Gifford menambahkan beberapa hal lagi yaitu bahwa manusia dapat digolongkan menjadi beberapa tipe lainnya, seperti : a. Environmental sensitivity di mana individu yang memiliki poin yang tinggi pada kategori ini cenderung secara benar dan cepat mampu mempersepsikan lingkungannya apakah baik atau buruk pada dirinya.

b. Environmental mobility yang dapat melihat sampai seberapa jauhindividusukamengunjungi tempat-tempat yang eksotik dan beresiko untuk dijelajahi.

c. Environmental control yang dapat dipergunakan untuk melihat sampai sejauh mana kepercayaan individu bahwa lingkungan alam mampu mengendalikan perilaku mereka.

d. Environmental risk taking di mana dapat diketahui seberapa jauh individu mau melakukan kegiatan-kegiatan yang beresiko tinggi di suatu lingkungan. Individu juga harus tahu bagaimana suatu lingkungan tergolong beresiko untuk didatangi dan melakukan aktivitas di sana serta tahu bagaimana mengambil resiko dan segala konseskuensinya.

Berdasarkan keterangan di atas dapat dipahami sampai sejauh mana alam dan lingkungan memiliki makna tertentu dalam hidup manusia. Maka tidak mengherankan jika maknamakna tersebut membentuk pola hubungan yang berbeda-beda pada 
setiap individu berdasarkan sifat dasar dan ketertarikan mereka pada lingkungannya. Ada yang begitu mencintai lingkungan sehingga memutuskan untuk bergabung dalam kelompok pecinta lingkungan sebagai aktivis, ada yang menyukai perjalanan ke tempat-tempat wisata bersejarah atau ada pula yang senang bertualang mencari tantangan di tempat-tempat tertentu. ${ }^{27}$

Bagi masyarakat Dasan Cermen pemahaman terhadap interkasi lingkungan menjadi suatu keharusan, karena selama ini orang sibuk hanya berinterkasi dengan dengan tuhan dan sesama saja, akan tetapi interaksi kepada lingkungan juga harus dilakukan. Dalam hal ini Ustaz Masri mengungkapkan:

...Interaksi dengan Tuhan dan manusia sangat penting, akan tetapi jangan sampai dilupakan juga hubungan manusia dengan lingkungannya sebagai tempat tinggal. Apalagi Dasan Cermen bertempat di kota, jadi harus terlihat bersih dan harus dijaga, karena malu juga sama tetangga dan orang-orang yang lewat kalau kotor-kotor. ${ }^{28}$

\section{E. Konsekuensi Ajaran Agama Masyarakat Dasan Cermen}

\section{Menjalankan Tradisi Keagamaan}

Tradisi keagamaa yang dimaksud disini adalah melaksankan kegiatan- kegiatan keagamaan sebagai konsekuensi dari ajaran agama masyarakat Dasan Cermen. Tradisi adat yang bernuansa keagamaan meliputi selamatan memperingati sembilan hari setelah meninggal, selamatan akad nikah, selamatan orang melahirkan, selamatan khitanan, peringatan maulid nabi, peringatan isra' mi' raj, dan peringatan tahun baru Islam dengan berbagai aktivitasnya dalam penerapan pada masyarakat dasan cermen perihal tersebut sudah lazim dam biasa dilakukan di wilayah itu, seperti peringatan sembilaan hari setelah meninggal aktivitas tersebut pasti dilakukan oleh warga yang kehilangan sanak keluarganya dengan mengumpulkan warga satu kampung untuk membacakan yasin dan tahlil yang faedah pahalanya dikhususkan kepada yang telah meninggal umunya kegiatan itu dilakukan sehari dua kali ritual yakni waktu setelah pelaksaaan sholat maghrib dan pagi setelah sholat shubuh. Zakat merupakan penyisihan dari sebagian harta yang dimiliki, pada prinsipnya zakat terbagi menjadi dua yaitu zakat fitrah dan zakat mal. Pertama, Zakat yang wajib dikeluarkan setiap muslim yakni zakat fitrah, yang artinya suatu ritual untuk mensucikan setiap diri manusia yang dilaksanakan setiap setahun sekali. Umumnya pada malam menjelang merayakan lebaran idhul fitri. Menurut bapak Sapri mengatakan :

27 Ibid., 158-159.

28 Wawancara dengan Ustaz Masri 45 Tahun, Tanggal 5 September 2016. 
......pada saat bulan ramadhan datang dan sudah waktunya untuk untuk berzakat saya dan keluarga biasanya mengeluarkan zakat setiap tahun berupa beras. $^{29}$

Kedua, Zakat mal merupakan zakat yang dikeluarkan bagi mereka yang memiliki kelebihan harta yang bergerak seperti hasil perkebunan, persawahan, dan ternak maupun tidak bergerak seperti kekayaan tanah dan emas yang telah mencapai nishob. Pada masyarakat Dasan Cermen hanya zakat fitrah yang biasa dilaksanakan setahun sekaliuntuk mensucikan setiap diri manusia saja. Karena umumnya mereka mengenai harta dan kekayaan hanya terbatas dengan satu rumah dan keluarga saja, sehingga secara otomatis tidak ada ketentuan dan kewajiban bagi mereka untuk mengeluarkan zakat mal. Dalam interaksi tolong menolong antara warga dalam masyarakat Dasan Cermen sudah berjalan cukup baik, tolong menolong yang bersifat materi seperti menyumbang warga lain yang punya hajatan nikah maupun khitanan maupun tidak bersifat materi seperti mengorbankan waktu dan tenaga, dengan ikut membantu salah satu warga yang memiliki hajat baik itu pernikahan, khitanan, dan roah sewaktu ada salah satu warga yang ingin meminta doa keselamatan untuk sanak keluarganya. Disamping itu, kegiatankegiatan keagamaan sangat beraneka ragam yang terdapat di Dasan Cermen, mulai dari pengajian untuk ibu-ibu dan

29 Wawancara dengan Bapak Sapri 42 Tahun, Tanggal 1 September 2016. juga untuk bapak-bapak. Pengajian yang dilakukan berbeda-beda, adapun kegiatan-kegiatan untuk kalangan anak-anak, remaja dan dewasa yakni ratiban. Ratiban ini adalah kegiatan yang dilakukan pada malam jumat untuk yasinan dan dilanjutkan dengan membaca amalan-amalan.

Ratiban merupakan kegiatan yang kami dilakukan pada malam jumat yang dimana anggotanya terdiri dari anakanak, remaja dan juga kalangan dewasa, kegiatan seperti ini pada dasarnya bertujuan untuk terus menjalankan ritual-ritual keagamaaan dan sekaligus menjalin silaturrahim diantara semua kalangan. ${ }^{30}$

\section{Norma-norma Keagamaan Sebagai Fakta Sosial}

Norma merupakan suatu nilai dan aturan dari sebuah kultur yang bernilai danberlangsungsecaraturuntemurun. Pelaksanaan norma Agama dalam kehidupan merupakan penerapan atau implementasi dari ajaran Agama Islam yang diperolehnya pada setiap diri manusia seperti memiliki sifat jujur, berperilaku sopan, mengucapkan salam dalam menyapa oranglain, selalu membaca do'a setiap melaksanakan segala aktivitas. Implementasi norma Agama muncul dalam kehidupan masyarakat dasan cermen, karena berdasarkan observasi lapangan faktor kebiasaan dengan kondisi lingkungan masyarakat yang berwatak keras dan kasar dalam melakukan

30 Wawancara dengan Syamsul Hadi 27 Tahun, tanggal 20 September 2016. 
interaksi dengan yang lainnya. Bisa dikatakan hampir semua agama dan juga kebudayaan memiliki ritual. Ritual menyiratkan suatu tindakan yang berulang secara terus menerus dan bertahap, berciri tradisional, menggambarkan tindakan yang menyimbolkan nilai-nilai kepercayaan masyarakat. Swantz mendefinisikan ritual sebagai cara masyarakat mengalami dan mengekspresikan simbol-simbol pemahaman mereka tentang hidup dan lalu mewariskannya kepada generasi selanjutnya. ${ }^{31}$

Berkaitan dengan norma-norma sosial dan ritual keagamaan, menurut Durkheim selalu ditemukan life cycle. Life cycle yang dimaaksud yakni dimana masyarakat memiliki dua gejala. Dan gejala ini selalu sifat serba dua dalam kehidupan masyarakat, yaitu antara waktu untuk bekerja untuk mencari rezeki dan waktu berkumpul untuk suatu perayaan suci. Kepercayaan yang memiliki dua sifat inilah bagi Durkheim yang mendasari kepercayaan agama. ${ }^{12}$

Dualitas kehidupan tersebut Durkheim menyebutnya dengan istilah "Yang Sakral" dan "Yang Profan". Halhal "yang sakral" menurut Durkheim adalah hal-hal yang dilindungi dan diisolasi oleh larangan-laranagan (tabu), sedangkan hal-hal "yang profan" adalah hal-hal tempat larangan larangan tersebut diterapkan dan harus tetap dibiarkan berjarak dari

31 Marsja-Liisa Swantz, Ritual and Symbol; in Transational Zaramo Society, (New York: CWK Gleerup, Lund 1970). hal-hal yang sakral. Yang Sakral adalah sesuatu yang terlarang dan terpisah. Definisi sakral sebagai sesuatu yang terlarang dan terpisah dirasakan lebih tepat untuk tidak menganggap bahwa yang sakral selalu terdapat sesuatu yang suci, sebab dalam hal yang profan pun terdapat sesuatu yang suci dan buruk, akan tetapi tidak akan berubah menjadi yang sakral. Sebaliknya, di dalam yang sakral juga bisa terdapat keburukan dan kebaikan sekaligus, tetapi tidak akan berubah menjadi yang profan. ${ }^{32}$

Berkaitan dengan norma-norma keagamaan sebagia fakta sosial sangat ditekankan oleh masyarakat Dasan Cermen sebagai implementasi dari pemahan masyarakatnya dari ceramah-ceramah dan pengajian yang mereka ikuti di masjid Darul Hidayah. Meskipun norma-norma kegamaan ini berangkat dari tradisi keagamaan, tetapi dalam pengaplikasiannya berbeda-beda dalam suatu tempat. Masyarakat Dasan Cermen misalnya dalam melaksanakan norma-norma serta ritual keagamaan seperti yang disebukan di atas, cukup berjalan dan tentu terdapat pemahaman masyarakat sepertiapayang disebut oleh Durkheim yakni yang sakral dan profan. Keberadaan norma-norma keagamaan sebagai fakta sosial pada masyarakat Dasan Cermen, tingkat keberagamaan dan solidaritas masyarakatpun bisa dibilang cukup solid, meskipun tidak

32 Emile Durkheim, The Elementary Forms of The Religious Life, (New York: Free Press, 1992), hlm. 72 . 
seperti yang dulu-dulu. Hal seperti ini yang dikatakan oleh Syamsul Hadi.

......memang tingkat keberagamaan masyarakat di desa kami sangat solid terutama dalam membangun masjid. Keberadaan masjid darul hidayah memangcukupmemberikanwarnapositif bagi masyarakat kami, meskipun masjid kami selalu dipenuhi oleh orangtua saja. Sedangkan anak-anak sudah memiliki tempat mengaji yakni dimusolla yang langsung dipimpin oleh ustaz Fizir. ${ }^{33}$

\section{Membangun Kesalehan Sosial}

Keberadaan masjid di Dasan Cermen juga tidak lepas untuk meingkatkan sikap kesalehan individu dan kesalehan sosial. Kesalehan individu yang dimaksud yakni semangat keberagamaan masyarakat dasan cermen tercermin dari efektifitas keberadaan masjid yang intens mengadakan kajian, atau tausiyah keagamaan untuk menciptakan kesalehanindividu. Adapaun kesalehan sosial yakni keberadaan masjid tidak hanyamenjalankanurusankeagamaan, solat mengaji dan lain sebagainya, namun fungsi masjid berdampak terhadap kesalehan sosial masyarakat. Dalam hal ini Ishak Hariyanto pernah menulis tentang kesalehan sosial, dimana dalam pandangannya bahwa Dalam konteks kesalehan sosial, saat ini banyaknya demoralisasi yang terjadi seperti: pemerkosaan, pembunuhan, korupsi merajalela, lalu dimankah

33 Wawancara dengan Syamsul Hadi 27 Tahun, Tanggal 20 September 2016. letak moralitas yang menjadi dasar aturan hidup.

Kehidupan ini akan rusak apabila tidak ada hal yang baik yang tertanam dalam diri kita, maka dalam hal ini Freud mengajarkan kita untuk melakukan hal yang baik dan menjaga libido (kenikmatan tanpa ada batasan) kita dari hal-hal yang bersifat amoral. Dalam konteks kesalehan sosial di sini harus adanya keseimbangan antara agen dan struktur seperti yang dikatan Giddens dalam teori strukturasinya, yakni adanya hubungna simbiotik antara agen dan struktur (generation of systems of interaction through duality of structure). Dalam persfektifnya Giddens ini ada tiga dimensi strukturasi yang dominan di dalam masyarakat yakni: sistem pemaknaan,dominasi, dan legitimasi. Dominasi kekuasaan sangat dipengaruhi oleh fasilitas yang ada, yakni ekonomi, politik, sosial, budaya, dan idiologi. Legitimasi sangat ditentukan oleh norma hukum agama dan tradisi. Maka dampak dari interaksi antar dominasi kekuasaandan penyalah gunaan legitimasiyang normatif akan menimbulkan kejahatan yang bersifat struktur.

Begitu pula dalam konteks moralitas harus berjalan antara kognitif dan rekognitif ${ }^{34}$ tanpa ada

34 Istilah rekognitif ini pada dasarnya pertamakali dipopulerkan oleh M. Husni Muadz seorang linguist alumni Arizona university yang saat ini mengembangkan teori pembelajaran rekognitif. Teori pembelajaran rekognitif saat ini sedang diaplikasikan di Desa Perampuan. Kata rekognitif ini sebenarnya diambil dari bahasa Inggris yakni recognition yang berarti pengakuan atau penghargaan. Akan tetapi dalam bahasa 
reduksi diantara satu sama lain, karena manusia pada dasarnya memiliki dua sistem kehidupan. Yaitu kehidupan rohani dan jasmani. Kedua-duanya bersifat simbiosis atau organik satu sama lain dan harus menyatu serta berdampingan. Jika sistem rohani sakit maka jasminipun akan mengalami sakit. Demikian juga sebaliknya, jika jasmani sakit, maka rohanipun ikut sakit. Oleh karena itu, dalam konteks Islam selalu mengajarkan konsep keseimbangan anatara kedua sistem tersebut karena, Islam bukan hanya mengjarkan kesalehan yang bersifat indidvidu saja akan tetapi kesalehan sosial. $^{35}$

Indonesia recognition ini diterjemahkan menjadi rekognitif. Dan kata rekognitif dalam konteks pembelajaran diartikan menjadi suatu konsep pembelajaran yang berbasiskan kemanusiaan dalam membangun hubungan antar sesama tanpa syarat (intersubyektifitas), bagaimana menjadi damai, saling berterima dalam hidup bermasyarakat. Hubungan berterima tersebut merupakan nilai-nilai yang harus ada dalam pembelajaran rekognitif. Tidak hanya itu, rekognitif juga adalah pembelajaran yang mengedepankan nilai-nilai moral seperti perilaku baik, kepatuhan, kemaafan, sabar, berterima satu sama lain, dermawan dan lain-lain. Disamping itu juga, pembelajaran rekognitif adalah suatu konsep pembelajaran non-material, dan selalu menyaratkan komunikasi verbal dan non verbal diantara semua makhluk untuk terus menjalin komunikasi dengan efektif. Dikatakan efektif karena ada perubahan diantara semua sistem sehingga untuk mewujudkan tujuan di atas maka nilai-nilai rekognitif atau perilaku-perilaku baik harus menjadi basis dalam setiap pembelajaran. Berkaitan rekognitif bisa dibaca dalam buku Anatomi Sistem Sosil Rekonstruksi Normalitas Relasi Intersubyektivitas Dengan Pendekatan Sistem. edisi revisi.

35 Ishak Hariyanto, "Etika Psikoanalisis Sigmund Freud Sebagai Landasan Kesalehan Sosial”, dalam jurnal Tazkiah, Fakultas Dakwah dan Komunikasi IAIN Mataram, 2016. Berkaitan dengan kesalehan sosial juga bisa dilacak dalam
Kesalehan sosial juga penting, jadi bukan saja kesalehan individu solat dan sujut di masjid, akan tetapi interaksi dengan oranglain untuk membangun kesalehan sosial tentu menjadi suatu keharusan. Jadi keberadaan masjid darul hidayah tidak semata-mata berfungsi sebagai tempat solat, akan tetapi kegiatankegiatan kemasyarakatan juga harus dilakukan sebagai bentuk kesalehan sosial. $^{36}$

\section{F. Faktor Yang Mempenggaruhi Pembangunan Masjid Darul Hidayah}

\section{Ideologi}

Setiap kuasa tindakan individu selalu di dasari oleh ideologi dari kepercayaan individu tersebut, begitupun halnya dengan tindakan sosial. Ia selalu terlatarbelakangi oleh iman dari para penganutnya. Semakin tinggi penghayatan atas keimanan seseorang dalam komunitas maka semakin militan juga gerakanya. Ideologi dalam konteks ini menjadi semacam pemantik suatu gerakan kolektif bersama untuk berjuang membangun dan meraih sesuatu. Ideologi terdapat pada internal setiap individu yang diyakini dan dihayati. Tidak ada yang dapat mengetahui seberapa kuat kadar ideologi (iman) seseorang. Ia dapat dilihat dari gerak memperjuangkan apa yang

buku M. Amin Syukur, Tasawuf Sosial, cet. Ke-II (Yogyakarta: Pustaka Pelajar, 2012 ), hlm. 61.

36 Wawancara dengan Syamsul Hadi 27 Tahun, 20 September 2016. 
dipercayanya tanpa meragukannya sama sekali.

Begitulah ideologi kolektif yang mendorong masyarakat Dasan Cermen untuk membangun Masjid Darul Hidayah. Bahkan hampir di seluruh wilayah di pulau Lombok memiliki ideologi yang sama ketika membangun masjid. Mereka dengan militan bekerjasama, mengakomodir masyarakat, mengumpulkan uang, berfikir, dan membangun masjid tanpa mau untuk diupah. Upah yang mereka harapkan bukan berbentuk materi duniawi akan tetapi memperjuangkan ideologi yang diyakininya;kepercayaan terhadap pahala dan dosa. Ada kepercayaan pada masyarakat Dasan Cermen muslim ketika menyumbangkan materi dan tenaga mereka demi berdirinya kembali masjid Darul Hidayah bahwa apa yang dilakukan akan dibalas kelak diakhirat berupa pahala membangun masjid. Masyarakat Dasan Cermen meniatkan segala tindakan mereka hanya untuk ibadah atas nama tuhan (lillahi taala), adapun pahala adalah bonus dari niat atas nama Tuhan. Berdirinya masjid Darul Hidayah tidak hanya didukung oleh masyarakat Dasan Cermen sendiri namun juga para pengguna jalan yang menyumbangkan uang mereka tatkala melewati masjid, sumbangansumbangan dari para usahawan serta masyarakat diluar Islam.

\section{Tuntutan Masyarakat}

Masjid Darul Hidayah dapat dikatakan berdiri di tempat yang strategis. Ia berada tepat di perbatasan antara Kabupaten Lombok Barat dan Kota Mataram. Selain itu terdapat simpang empat yang mengarah ke Kecamatan Labuapi dan Desa Bengkel Kecamatan Kediri Kabupaten Lombok Barat, Karang Genteng dan Abian Tubuh kota Mataram. Di depan sayap kiri dan kanan masjid, terdapat lampu lalu lintas yang mengharuskan pengendara untuk berhenti, oleh karenanya menjadi hal yang biasa para pengguna jalan ketika melemparkan uang ke masjid atas dorongan bersedekah untuk membangun masjid. Para pengguna jalan itupun beragam yang tidak dapat diidentifikasi siapa mereka, kerja di mana dan bahkan ideologinya. Atas sumbangan dari pengguna jalan tersebut direpresentasikan sebagai suruhan untuk merenovasi bahkan membangun kembali masjid Darul Hidayah oleh masyarakat Dasan Cermen.

"Pada awalnya kami tidak menduga bahwa dana yang terkumpul dari sumbangan para pengguna jalan begitu banyak dan massif... setelah kami tunggu semakin lama semakin banyak bahkan melebihi jumlah hasil iuaran masyarakat dasan cermen sendiri.... kami merasa semangat masyarakat pengguna jalan dalam menyedekahkan uang mereka adalah bentuk dari teguran untuk membangun kembali masjid... pada tahun 2005 kami bersepakat untuk membangun masjid di atas masjid 
yang lama dengan arsitektur yang lebih bagus" 37

Semangat kolektif masyarakat Dasan Cermen serta didorong oleh semangat para pengguna jalan dalam beribadah membangun masjid memberikan dampak positif, hanya rentang waktu empat tahun 2005 sampai dengan tahun 2009 masjid tersebut berdiri, ini adalah sebuah prestasi di mana masyarakat lainnya ketika membangun masjid tidak sampai empat tahun sebagaimana masyarakat dasan cermen. Mereka butuh enam hingga sepuluh tahun untuk benar-benar jadi.

\section{G. Penutup}

Keberagamaan adalah tingkat pengetahuan, keyakinan, pelaksanaan dan penghayatan seseorang atas ajaran Agama yang diyakininya, atau suatu sikap penyerahan diri kepada suatu kekuatan yang ada diluar dirinya yang diwujudkan dalam aktivitas dan perilaku individu sehari-sehari meliputilima aspek-aspekatau dimensi yaitu keyakinan agama, peribadatan atau praktik agama,pengetahuan agama, penghayatan, pengamalan agama. Dalam keberagamaan ini tentu dalam pengaplikasiannya berbeda-beda, dan perbedaan itu pula terlihat pada masyarakat Dasan Cermen dalam menjalankan tingkat keberagamaanya. Semangat keberagamaan dan solidaritas

37 Wawancara dengan Amak Sehun 47 Tahun, 11 September 2016. membangun masjid pada masyarakat Dasan Cermen mencerminkan identitas muslim kesasakan yang komunal di tengah-tangah masyarakat perkotaan Mataram. Sistem solidaritas yang tengah terbangun secara turun temurun memproduksi sikap toleransi antar budaya, tingkat sosial dan agama. Masjid Darul Hidayah menjadi semacam identitas kolektif keberadaan masyarakat muslim dan tingkat penghayatan mereka terhadap Tuhan, hubungan dengan sesama, dan hubungan dengan lingkungan. Bangunan masjid, sebagaimana sudah dipaparkan di atas adalah sebuah product dari solidaritas mekanik rural society dan organik uban Society sebagai penggerak di luar dirinya serta fakta sosial yang kami sebut ideologi keagamaan. Solidaritas yang terjalin pada masyarakat Dasan Cermen bersifat mekanik, biasa berlaku pada masyarakat pedesaan, awik-awik dan organik perkotaan. Mekanik karena solidaritas mereka digerakkan oleh ketokohan para tetua Tuan guru, ustadz, di lingkungan.

\section{Daftar Pustaka}

A.R. Wallace. 1986-1869. the Land of the Orang Utan, and the Bird of Paradise, Singapore University Press.

A.R. Wallace. 2009. Kepulauan Nusantara Sebuah Kisah Perjalanan, Kajian Manusia dan Alam, Terj. Tim Komunitas 
Bambu, Depok: Komunitas Bambu.

Amal, Adnan, Taufik. 2001. Rekonstruksi Sejarah Al-Qur'an, Yogyakarta: Pustaka Pelajar.

Amril Mansur. 2014. "Masjid Dan

Transformasi Sosial Etis Upaya Pemberdayaan Masjid Dalam Kehidupan Sosial" Jurnal Innovation, Vol. VII No. 14 JuliDesember.

Ancok, Djamaludin dan Suroso.1994. Psikologi Islam.

---------. 2003 . Pengantar Buku Psikologi Sholat.

Ansari, Haq, Abdul, Muhammad. 1986. Sufism and Shari'ah, A Study oF Shaykh Ahmad Sirhindi's Effort To Reform Sufism, London: The Islamic Foundation.

Ari Wibowo.http:// dema-stain. blogspot.com/2011/10/ makalah-wilayah-kajiansosiologi-agama.html.

Badan Pusat Statistik Propinsi Nusa Tenggara Barat 2013.

Bastin, John dan Jullian Benda. 1968. A History of Modern Southeast Asia .New Jersey: Prentice.

Beth B. Hess, dkk. 1982.Sociology, New York: Macmillan Publishing Company.

Campbel, Tom. 2001. Tujuh Teori Sosial, Ter. Budi Hardiman, Yogyakarta: Kanisius.
Chodjin, Ahmad. 2002. Jalan Pencerahan, Jakarta: PT Serambi Ilmu Semesta.

Dalmeri. 2014. "Revitalisasi Fungsi Masjid Sebagai Pusat Ekonomi dan Dakwah Multikultural" JurnalWalisongo, Vol. 22, Nomor 2, November.

Data Kelurahan, Profil Kelurahan Dasan Cermen.

Durkheim, Emile. 1992.The Elementary Forms of The Religious Life, (New York: Free Press.

Elvinaro Erdianto. 2010. Metodologi Penelitian Untuk Public Relations Kuantitatif dan Kualitatif, Bandung: Simbiosa Rekatama Media.

Fathurrosid. 2005. "Status Sosial Masyarakat dan Pengamalan Ajaran Agama Islam Pada Masyarakat Perkotaan”, TesisTesis tidak diterbitkan, IAIN Sunan Ampel Surabaya.

Hajar, Ibnu "Kemerosotan Religiusitas" Artikel pada www. Suaramerdeka.com Date: Sat, 6 Aug 2005 04:27:31 +0200

Hariyanto, Ishak, Meniti Renaisans Lewat Pembelajaran Rekognitif di Lombok, Dalam proses penerbitan, Mataram: Sanabil.

Sigmund Freud Sebagai Landasan Kesalehan Sosial", dalam jurnal Tazkiah, Vol. 5, No 5 Juni- 
Desember Fakultas Dakwah dan Komunikasi IAIN Mataram,.

Hendropuspito.1983.

Sosiologi

Agama, Yogyakarta: Kanisius.

http:/ / inifanfan.blogspot. co.id/2013/09/sosiologi-klasiksolidaritas-sosial_3514.html.

http:// news.detik.com/ read/2013/

$10 / 01 / 123736 / 2374226 / 1513 /$

ditemukan-sisa-letusan-gunungrinjani-di-kedua-kutub-bumi), 30-04-2015, 12:00. kompas.com

http:/ / sains.kompas.com / $\mathrm{read} / 2013 / 10 / 02 / 2250336 /$ Letusan.Samalas.dalam.Babad. Lombok.yang. Melumpuhkan. Dunia), 30-04-2015, 13:00.

Kaelan. 2005. Metode Penelitian Kualitatif Bidang Filsafat, Yogyakarta: Paradigm.

Kanwil. 2015. Badan Pertanahan Nasional Provinsi Nusa Tenggara Barat

Lukman, Lalu. 2006. Tata Budaya Adat Sasak di Lombok, Kumpulan Tata Budaya Lombok.

Lombok Tengah dalam Angka Tahun 2012.

Lombok Utara Dalam Angka 2014.

Mardalis. 2004. Metode Penelitian, Jakarta:PT.Bumi Aksara.

Marsja-Liisa Swantz. 1970.Ritual and Symbol; in Transational Zaramo Society, New York: CWK Gleerup, Lund.
Marzuki, Pembinaan Akhlak Mulia Dalam Hubungan Antar Manusia Dalam Perspektif Islam, tulisan pdf.

Moleong. 1994. Metode Penelitian Kualitatif, Bandung: Remaja Rosdakarya.

Muadz, Husni, M., 2014. Anatomi Sistem Sosial Rekonstruksi Normalitas Relasi Intersubyektivitas Dengan Pendekatan Sistem, Mataram: Institut Pembelajaran Gelar Hidup IPGH.

Mulyati, Sri. 1992. Sufism In Indonesia: An Anlysis Of Nawawi AlBanteni's Salim Al-Fudala, Institute Of Islamic Studies McGill University Montreal. P.Q Canada.

Muslehuddin. 2007. "Religiusitas Masyarakat Pesisir" Tesis tidak diterbitkan, UIN Wali Songo Semarang.

Nina W. Syam. 2012. Sosial Sebagai Akar Ilmu Komunikasi, Badung: Simbiosa Rekatama Media.

NTB Dalam Angka 2011.

Rahardjo, Wahyu. 2006. "Hubungan Manusia-Lingkungan: Sebuah RefleksiSingkat" JurnalPenelitian Psikologi, Fakultas Psikologi Universitas Gunadarma no. 2, vol. 11, Desember.

Ratna, Kutha, Nyoman. 2010. Metodologi Penelitian Kajian Budaya dan Ilmu Humaniora 
Pada Umumnya, Yogyakarta: Pustaka Pelajar.

Razak, Yusron. 2008. Sosiologi Sebuah Pengantar: Tinjauan Pemikiran Sosiologi Perspektif Islam, Tangerang: Mitra Sejahtera.

Rukmana, Nana. 2002. Masjid dan Dakwah, Jakarta: Al Mawardi Prima.

Sen, Tan, Ho, Cheng. 2010. Penyebar Islam dari China ke Nusantara Jakarta: Penerbit Buku Kompas.

Shadily Hassan. 1983. Sosiologi Untuk Masyarakat Indonesia, Jakarta: Bina Aksara.

Soejono Soekamto. 2002. Pengantar Sosiologi, (Erlangga: Surbaya).

Soekanto, Soerjono. 1982. Sosiologi Suatu Pengantar, Jakarta:CV Rajawali.

Soemardjan Selo dan Soelaeman Soemardi. 1974. Setangkai Bunga sosiologi, Jakarta: Lembaga Penerbitan FEUI.

Sudirman. 2007. Gumi Sasak dalam Sejarah, Pringgabaya: KSU Prima Guna.

Sugiyono. 2013. Metode Penelitian Kombinasi, Bandung: Alfabeta.

Syah, Hidayat. 2013. "Urbanisasi dan Modernisasi Studi Tentang Perubahan Sistem Nilai Budaya Masyarakat Urban di Pangkalan Kerinci Kabupaten Pelalawan”Jurnal Toleransi, Vol. 5 No. 1 Januari-Juni.

Syakur, Abd, Ahmad. 2006. Islam dan Kebudayaan Akulturasi Nilai-
Nilai Islam dalam Budaya Sasak, Yogyakarta: Adab Press.

Syukur, Amin, M. 2012. Tasawuf Sosial, cet. Ke-II, Yogyakarta: Pustaka Pelajar.

T.W. Arnold. 1968. The Preaching of Islam: A History of The Propagation of The Muslim Faith, Lahore SA Muhammad Asraf.

Wawancara dengan Amaq Burhan 50 Tahun, Tanggal 12 Agustus 2016.

Wawancara dengan Bapak Andi 40 Tahun, Tanggal 19 Agustus 2016.

Wawancara dengan Bapak Sapri 42 Tahun, Tanggal 1 September 2016.

Wawancara dengan Syamsul Hadi 27 Tahun, Tanggal 3 September 2016.

Wawancara dengan Ustaz Masri 45 Tahun, Tanggal 5 September 2016.

Wawancara dengan Pak Udin 45 Tahun, Tanggal 5 September 2016.

Wawancara dengan Bapak Hanan 43 Tahun, Tanggal 10 September 2016.

Wawancara dengan Amak Sehun 47 Tahun, 11 September 2016.

Wawancara dengan Pak Anom 50 Tahun, Tanggal 12 September 2016. 